\title{
Trophic structure of a floodplain fish assemblage in the upper Amazon basin, Bolivia
}

\author{
Danny Rejas \\ Unidad de Limnología y Recursos Acuáticos, Universidad Mayor de San Simón, PO Box 992, Cochabamba, Bolivia; \\ dannyrejas.a@fcyt.umss.edu.bo,danny.rejas@gmail.com
}

Received 12-II-2018. Corrected 28-V-2018. Accepted 20-VI-2018.

\begin{abstract}
Amazonian fish assemblages are typically high in species diversity and trophic complexity. Stable isotopes are valuable tools to describe the trophic structure of such assemblages, providing useful information for conservation and ecological management. This study aimed at estimating the relative contribution of the different basal carbon sources to the diet of primary consumer fishes (herbivores and detritivores), and determining the trophic position (TP) of the dominant fishes from each trophic guild (herbivores, detritivores, invertivores and piscivores). For this purpose we analyzed stable isotope ratios of carbon $\left(\delta^{13} \mathrm{C}\right)$ and nitrogen $\left(\delta^{15} \mathrm{~N}\right)$ in potential food sources, and muscle tissue of fishes in five oxbow lakes located in the floodplain of River Ichilo, Bolivia. Terrestrial plants and $\mathrm{C}_{3}$ aquatic macrophytes were the major carbon source contributing to the diet of herbivorous fishes, whereas particulate organic matter (POM) contributed more to the diet of detritivore fishes. In general, $\mathrm{C}_{4}$ aquatic macrophytes contributed little to the diet of herbivores and detritivores. However, we found a relatively high contribution of $\mathrm{C}_{4}$ macrophytes $(28 \%)$ to the diet of the herbivores Mylossoma duriventre and Schizodon fasciatus. We found a good agreement between our estimated TP values and the trophic group assigned based on diet composition from literature. The herbivore $M$. duriventre was at the bottom of the food web, being the baseline organism $(\mathrm{TP}=2)$. The remaining primary consumers (herbivores and algivore/ detritivores) exhibited relatively high TP values (2.3-2.9), probably due to their opportunistic feeding behavior. Omnivore/invertivore species studied displayed TP values near the 3.0 value expected for secondary consumers. Piscivore fishes were at the top TP, with TP values varying from 3.3 (Serrasalmus spilopleura and Serrasalmus rhombeus) to 3.8 (Pseudoplatystoma fasciatum). The fact that detritivore fishes, the most abundant food source for piscivores, occupy relatively high TPs determines that food chains in these particular Amazonian floodplains are longer than previously thought. Rev. Biol. Trop. 66(3): 1258-1271. Epub 2018 September 01.
\end{abstract}

Key words: stable isotopes; trophic position; trophic guilds; carbon sources; food chain.

Food web studies are fundamental for ecological research. Description of food web structure provides information on carbon and nutrients flux, connectivity and food chain length (Abrantes, Barnett, \& Bouillon, 2014). This information is extremely useful for conservation and ecological management, as indicators of productivity (Thébault \& Loreau, 2003), ecosystem perturbation (Cucherousset, Bouletreau, Martino, Roussel, \& Santoul, 2012; McMeans, Rooney, Arts, \& Fisk, 2013; Busst \& Britton, 2017), and contaminant biomagnification (Pouilly et al., 2013; Marshall , Forsberg, \& Peleja, 2016).
Amazonian fish assemblages present high taxonomic diversity and trophic complexity (Jepsen \& Winemiller, 2002), comprising several trophic guilds from primary consumers to carnivore species. The trophic structure of such assemblages is better described assigning organisms a continuous measure of trophic position (Vander-Zanden \& Rasmussen, 1999). Quantitative gut content data of fish stomachs can provide detailed information on fish diets but are difficult to collect. Moreover, they represent only recently ingested food, contain a fraction of unidentifiable biomass and may include a fraction that is not digestible $(\mathrm{Gu}$, 
Schelske, \& Hoyer, 1997; Manetta, BeneditoCecilio, \& Martinelli, 2003). Stable carbon and nitrogen isotope ratios $\left(\delta^{13} \mathrm{C}\right.$ and $\delta^{15} \mathrm{~N}$, respectively) integrate temporal and spatial variation in feeding and reflect the materials that have been actually incorporated into animal tissue (Fry, 2006). Thus, stable isotopes of carbon and nitrogen have been extensively used to identify carbon sources and assess trophic structure in freshwater food webs during the last two decades (Post, 2002; Herwig, Soluk, Dettmers, \& Wahl, 2004; Coat, Monti, Bouchon, \& Lepoint, 2009; Abrantes et al., 2014).

Pioneer works of Hamilton, Lewis Jr., and Sippel (1992) and Forsberg, Martinelli, Victoria, and Bonassi (1993) in neotropical freshwaters utilized stable isotope data for identifying the autotrophic carbon sources for aquatic animals in the Orinoco River and Amazon River basins, respectively. Since then, food web structure of aquatic ecosystems in the Paraná (Wantzen, de Arruda-Machado, Voss, Boriss, \& Junk, 2002; Manetta et al., 2003; Lopes, Benedito, \& Martinelli, 2009; de Carvalho, de Castro, Callisto, Moreira, \& Pompeu, 2017), Orinoco (Lewis Jr., Hamilton, Rodriguez, Saunders III, \& Lasi, 2001; Jepsen \& Winemiller, 2002) and Amazon basins (Leite, Araújo-Lima, Victoria, \& Martinelli, 2002; Pouilly et al., 2013; Mortillaro et al., 2015) have been studied using ${ }^{13} \mathrm{C}$ and ${ }^{15} \mathrm{~N}$ stable isotopes.

Nevertheless, the knowledge on food web structure of neotropical floodplains is fragmented and little attention has been paid to study the upper Amazon basin. Due to their proximity to headwaters of the Andes Mountain Range, rivers on the Southwestern side of the Amazon basin feature a polymodal hydrological cycle, with numerous peaks caused by local precipitation and extremely short flooding periods compared to those from the central and lower Amazon (Rejas, 2004; Maldonado, Goitia, \& Rejas, 2005). Since the flood pulse is the driving force responsible for the productivity and interactions in floodplain systems (Junk, Bayley, \& Sparks, 1989), carbon sources for fishes on the lower trophic level may differ, as well as trophic position of fishes from different guilds.

Therefore, the study aimed at: 1) estimating the relative contribution of the different basal carbon sources to the diet of primary consumer fish species, and 2) determining the trophic position of the dominant fishes from each guild (herbivores, detritivores, invertivores and piscivores).

\section{MATERIALS AND METHODS}

We collected samples from five oxbow lakes located in the floodplain of River Ichilo, Bolivia (between 1616'12" - 16²49'48" S \& 643' $48^{\prime \prime}$ - 6448'00" W; 170 - 200 m.a.s.l.; Fig. 1). The climate in the region is tropical, with mean annual temperatures exceeding 25 ${ }^{\circ} \mathrm{C}$ and annual average precipitations between 2000 and $2500 \mathrm{~mm}$. Ichilo is a white water river, characterized by high loads of suspended sediments and low transparence (Sioli, 1984). It presents a polymodal hydrological cycle, with numerous peaks caused by local precipitation (Rejas, Muylaert, \& De Meester, 2005). Floodplain lakes of white-water rivers or "várzea lakes" are abundant in the floodplain of river Ichilo, and are linked to the main channel of the river during the annual high water period. Lakes were selected based on accessibility, since they are very similar in terms of morphology, physical and chemical characteristics, and fish species composition (Carvajal \& Maldonado, 2005).

These lakes are surrounded by a dense rainforest that supplies large amounts of allochthonous organic matter. Aquatic macrophytes are present in all sampled lakes, covering at most $20 \%$ of the surface. The $\mathrm{C}_{4}$ West Indian marsh grass (Hymenachne amplexicaulis) is the dominant species (70-80\%), with the remaining coverage consisting of variable proportions of the $\mathrm{C}_{4}$-grass Water paspalum (Paspalum repens) and $\mathrm{C}_{3}$ macrophytes: Water hyacinth (Eichhornia crassipes), Water lettuce (Pistia stratioides), Polygonum sp. and Cyperus sp.

We took samples and collected fishes during the low water season (August-October) in 

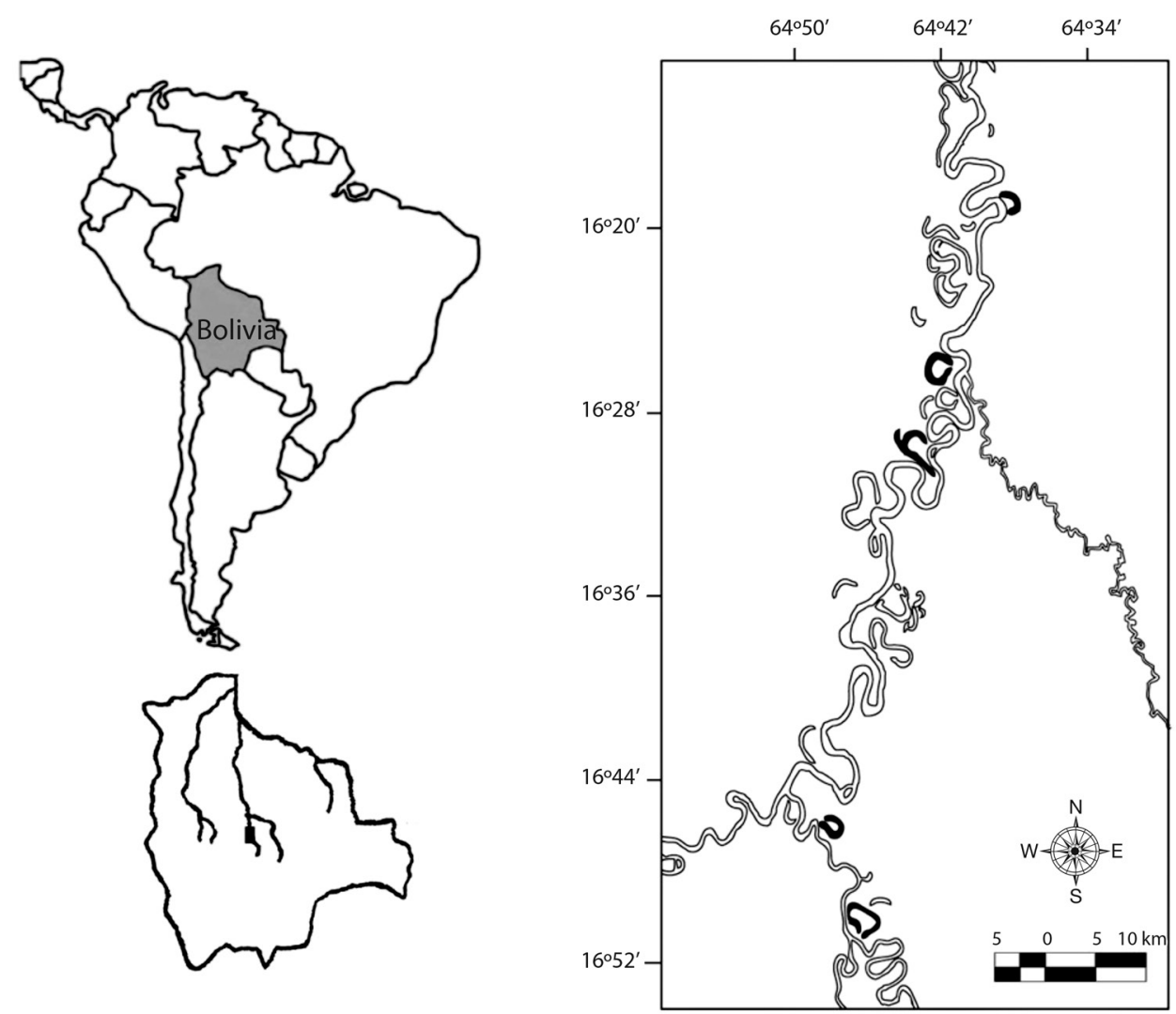

Fig. 1. The study sites, showing Bolivia in South America and the study area in Bolivia. Sampled lakes are marked in black.

2001, 2002, 2011 and 2012. At this period of the year, the lakes have been isolated from the river for at least four months, preventing us from sampling recently arrived migrants. We captured fishes with gillnets having knot-toknot distances of 10, 20, 30, 40 and $60 \mathrm{~mm}$. Muscle tissue was taken from the dorsal part of each fish. Large species (Pseudoplatystoma fasciatum, Pseudoplatystoma tigrinum and Colossoma macropomum) were sampled in situ from individuals captured by professional fishermen. Only adult individuals were sampled to obtain an isotopic signature that is representative of their diet over long periods of time (Post, 2002).

We sampled basal carbon sources: $\mathrm{C}_{3}$ and $\mathrm{C}_{4}$ aquatic macrophytes (all taxa mentioned above), terrestrial plants from the surrounding rainforest (Ficus, Inga, Spondias, and several other arboreal taxa), leaf litter from the bottom of the lake, and particulate organic matter (POM) as a surrogate for phytoplankton. All plant material was rinsed with deionised water. POM samples were collected integrating water from the upper $1.5 \mathrm{~m}$ of the water column, screened through $20-\mu \mathrm{m}$ mesh, and filtered onto precombusted glassfibre Whatman $\mathrm{GF} / \mathrm{F}$ filters. All samples were placed in crio-vials, stored frozen and transported to the laboratory. Samples were thawed, dehydrated and grounded to a fine powder. Approximately $1 \mathrm{mg}$ of dry sample material was packed into tin capsules. Measurements of $\delta^{13} \mathrm{C}$ and $\delta^{15} \mathrm{~N}$ were performed at the Laboratory of Analytical and Environmental Chemistry (VUB, Belgium; samples collected in 2001 and 2002) and at the UC Davis Stable Isotope Facility laboratory 
(University of California, Davis, USA; samples collected in 2011 and 2012).

Stable isotope ratios are reported in parts per thousand (\%o) relative to international standards: Pee Dee belemnite (PDB) for carbon and atmospheric $\mathrm{N}$ for nitrogen. Isotope ratios are defined as:

$$
\delta^{15} N \text { or } \delta^{13} C=\left(\frac{R_{\text {sample }}}{R_{\text {standard }}}-1\right) \times 10^{3}
$$

Where $\mathrm{R}={ }^{15} N /{ }^{14} N$ or ${ }^{13} C /{ }^{12} C$ (Jepsen \& Winemiller, 2002).

For all carbon sources, and fish species with at least three samples for each sampling campaign (Potamorhina altamazonica, Prochilodus nigricans and Pygocentrus nattereri), we tested for differences in the dual isotopic signal of $\delta^{13} \mathrm{C}$ and $\delta^{15} \mathrm{~N}$ between sampling campaigns $(2001 / 2002$ and 2011/2012) with a K-nearest neighbor randomization test (Rosing, BenDavid, \& Barry, 1998). We found no significant differences; therefore, data from both sampling campaigns were pooled together. Mixing models require that all sources are significantly different in bivariate space; we employed a K-nearest neighbor randomization test (Rosing et al., 1998). Groups that did not show significant differences were combined (Matsubayashi et al., 2015).

We estimated the relative contribution of each basal carbon source to the isotopic signal of primary consumer fish species (herbivores and detritivores; see species guilds in Table 1) applying a Bayesian mixing model (SIAR R-package) (Parnell, Inger, Bearhop, \& Jackson, 2010). Mean isotope fractionation values were set to $1.3(\mathrm{SD}=0.3) \%$ and 2.8 $(\mathrm{SD}=0.4) \%$ for $\delta^{13} \mathrm{C}$ and $\delta^{15} \mathrm{~N}$, respectively (McCutchan Jr., Lewis Jr., Kendall, \& McGrath, 2003).

We used $\delta^{15} \mathrm{~N}$ to estimate consumer trophic position (Minagawa \& Wada, 1984). Relative individual trophic position (TP) was calculated by the formula:

$$
\mathrm{TP}=\lambda+\left(\delta^{15} \mathrm{~N}_{\text {fish }}-\delta^{15} \mathrm{~N}_{\text {base }}\right) / \Delta
$$

Where $\lambda$ is the trophic position of the organism used to estimate $\delta^{15} \mathrm{~N}_{\text {base }}$ and $\Delta$ is the $\mathrm{N}$ isotopic fractionation in \%o that occurs between each trophic level. The isotopic fractionation value $\Delta$ was set to $2.8 \%$ (McCutchan Jr. et al., 2003). $\delta^{15} \mathrm{~N}_{\text {base }}$ was estimated using mean $\delta^{15} \mathrm{~N}$ of Mylossoma duriventre, the herbivore species with the most depleted isotopic $\delta^{15} \mathrm{~N}$ signal, which then was set to 2 .

\section{RESULTS}

Isotopic ratios of basal carbon sources: All basal carbon sources differed significantly in their (dual) isotopic signal (k-nearest neighbor randomization test, $\mathrm{p}$-values $<0.005$ ) except for terrestrial plants and leaf litter $(\mathrm{P}=$ 0.15 ), which were pooled together for posterior analyses. $\mathrm{C}_{4}$ aquatic macrophytes were the least ${ }^{13} \mathrm{C}$-depleted sources, with a mean value of $-12.6 \pm 0.4 \%$ (mean $\pm \mathrm{SD}) . \mathrm{C}_{3}$ macrophytes and terrestrial vegetation were considerably more ${ }^{13} \mathrm{C}$-depleted, with mean values $( \pm \mathrm{SD})$ of $-28.3 \pm 1.5 \%$ and $-31.6 \pm 1.1 \%$, respectively. POM had the most depleted $\delta^{13} \mathrm{C}$ value: -37.1 $\pm 1.1 \%$ ). Mean $\delta^{15} \mathrm{~N}$-value in terrestrial vegetation $(+2.3 \pm 1.6 \%$ o) was considerably lower than in $\mathrm{C}_{4}(+6.0 \pm 2.9 \%)$ and $\mathrm{C}_{3}(+6.0 \pm 2.4$ $\%$ ) aquatic macrophytes. Mean $\delta^{15} \mathrm{~N}$ value of POM was $+4.1 \pm 2.7$ (Table 1 ).

Isotopic ratios of fishes: Mean $\delta^{13} \mathrm{C}$ values of fishes varied between $-36.8 \pm 2.2 \%$ (Moenkhausia dichroura) and -24.9 $\pm 2.7 \%$ (M. duriventre). The range of $\delta^{13} \mathrm{C}$ signatures of fish overlapped with the signatures of basal carbon sources, except for $\mathrm{C}_{4}$ aquatic macrophytes that were ${ }^{13} \mathrm{C}$-enriched compared to fish. Mean $\delta^{15} \mathrm{~N}$-values varied between $6.0 \pm$ $1.3 \%$ (M. duriventre) and $11.1 \pm 0.4 \%$ \% $(P$. fasciatum). All fish species had higher average $\delta^{15} \mathrm{~N}$-values than the basal carbon sources, except for $M$. duriventre that had an average $\delta^{15} \mathrm{~N}$-value as low as the most ${ }^{15} \mathrm{~N}$-enriched carbon sources $\left(\mathrm{C}_{3}\right.$ and $\mathrm{C}_{4}$ aquatic macrophytes). Herbivores were the least ${ }^{15} \mathrm{~N}$-enriched fish species, whereas piscivores were the most ${ }^{15} \mathrm{~N}$-enriched fish species (Table 1, Fig. 2). 


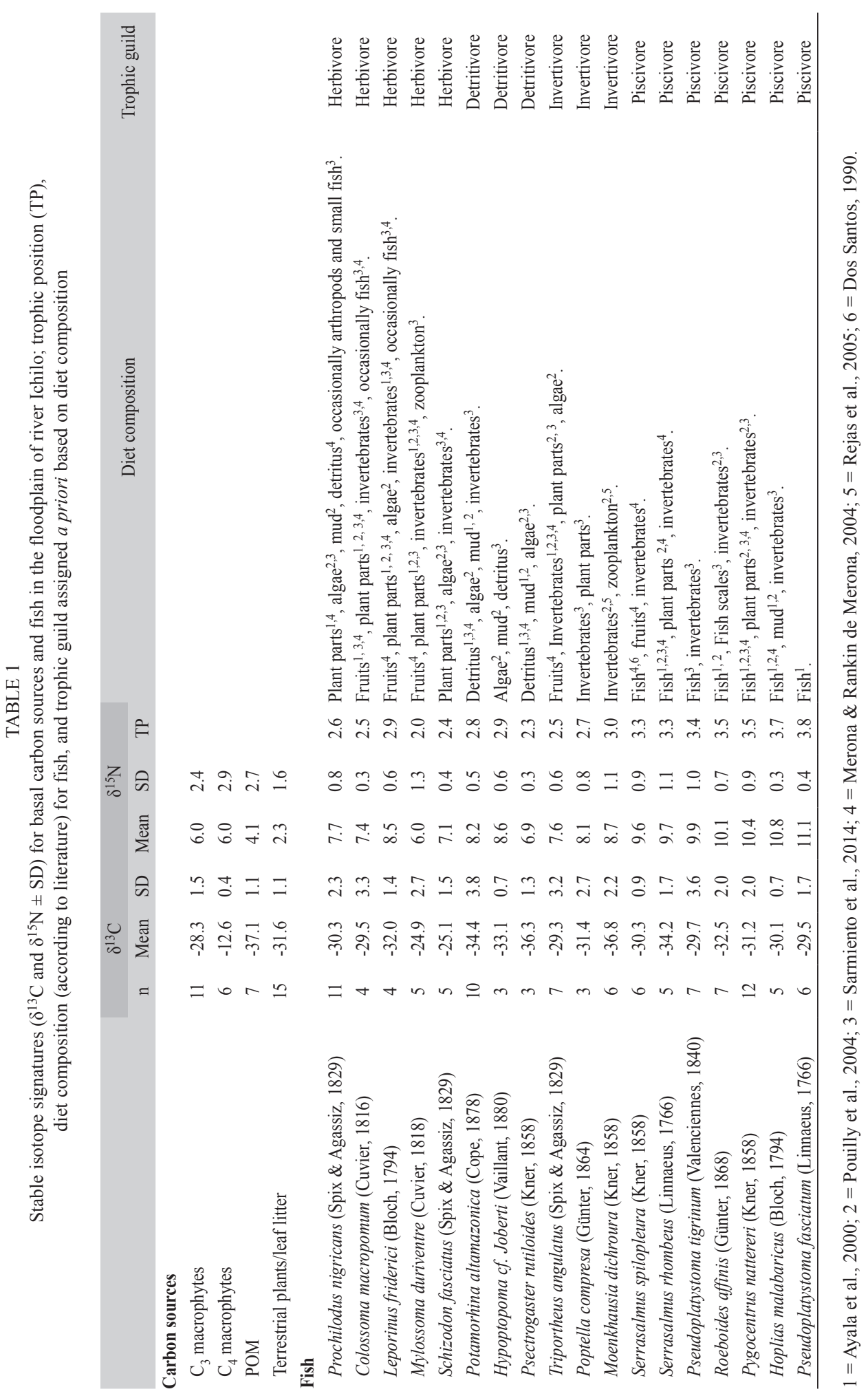


Relative contribution of basal carbon sources to primary consumer fishes: Terrestrial plants and aquatic macrophytes were the major carbon source contributing to the diet of herbivore fishes, whereas POM contributed more to the diet of detritivore fishes (Table 2). All carbon sources contributed similarly to the diet of the herbivores $P$. nigricans and $C$. macropomum (around $30 \%$ ) except for $\mathrm{C}_{4}$ macrophytes, which contributed only $7 \%$ and $15 \%$, respectively. In contrast, we found a relatively high contribution of $\mathrm{C}_{4}$ macrophytes for the herbivores $M$. duriventre and Schizodon fasciatus; $28 \%$ in both cases), with similar contributions from the remaining carbon sources.
Relative contribution of carbon sources for the herbivore Leporinus friderici was similar to that for the detritivores, with $46 \%$ contribution of POM and $27 \%$ of $\mathrm{C}_{3}$ aquatic macrophytes. POM contributed nearly $50 \%$ of the carbon for the detritivores $P$. altamazonica and Hypoptopoma joberti, with $\mathrm{C}_{3}$ macrophytes being the second contributor (32\% and $21 \%$, respectively). Although POM contributed less for the detritivore Psectrogaster rutiloides (31 $\%$ ), it remained a major $\mathrm{C}$ source, followed by terrestrial plants $(30 \%)$.

Trophic position: Trophic position is shown on Table 2. Herbivore fishes showed

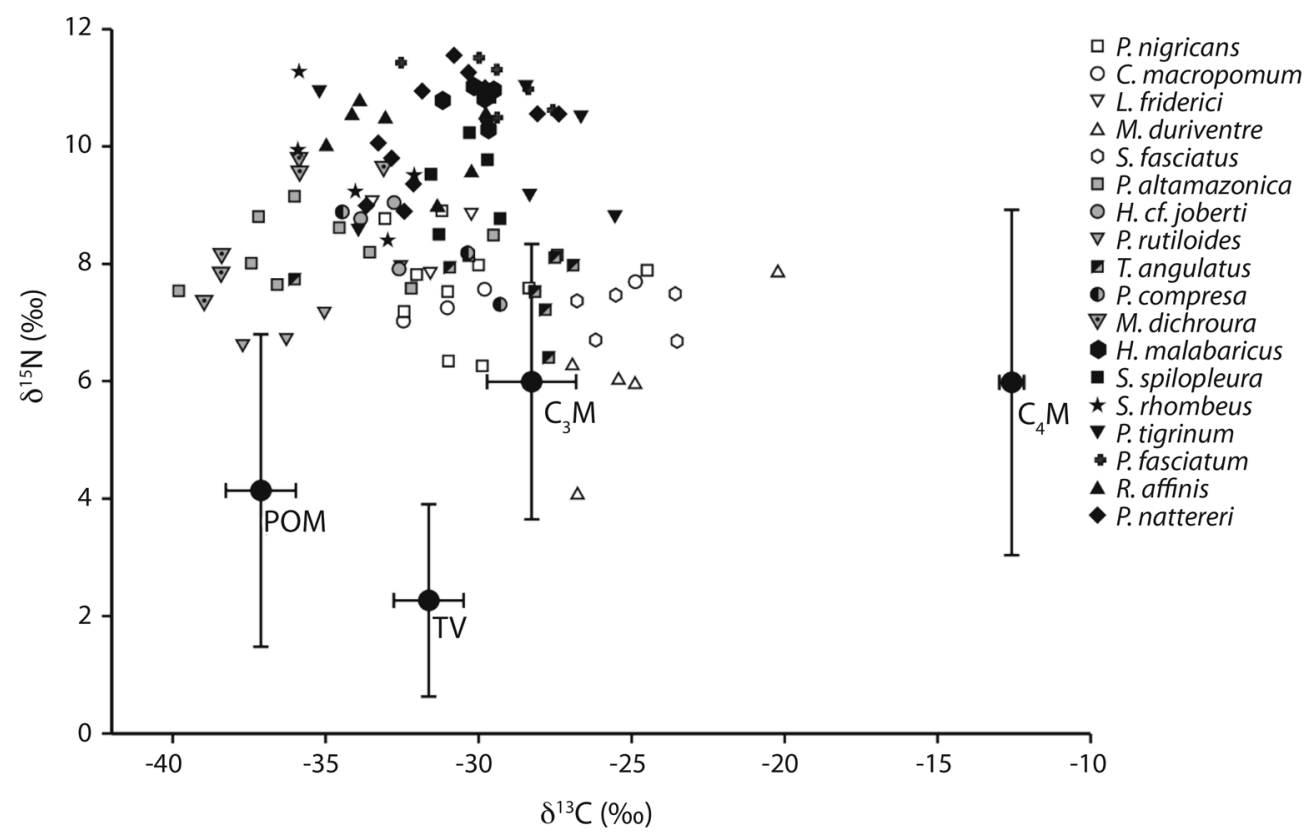

Fig. 2. Values of $\delta^{13} \mathrm{C}$ and $\delta^{15} \mathrm{~N}$ for fishes (small symbols) and mean values $( \pm \mathrm{SD})$ for basal carbon sources (large symbols) in the floodplain of River Ichilo, Bolivia. $\mathrm{POM}=$ particulate organic matter, $\mathrm{TV}=$ terrestrial vegetation, $\mathrm{C}_{3} \mathrm{M}=\mathrm{C}_{3}$ aquatic macrophytes, $\mathrm{C}_{4} \mathrm{M}=\mathrm{C}_{4}$ aquatic macrophytes. Clear symbols represent herbivore species, gray symbols represent detritivore species, black/gray symbols represent invertivore species and black symbols represent piscivore species. 
TABLE 2

C-sources relative contributions (mean $\% \pm \mathrm{SD}$, estimated by SIAR mixing model) to primary consumer fish species (herbivores and detritivores)

\begin{tabular}{|c|c|c|c|c|c|c|c|c|}
\hline \multirow{2}{*}{ Fish/C-source } & \multicolumn{2}{|c|}{$\mathrm{C}_{3}$ macrophytes } & \multicolumn{2}{|c|}{$\mathrm{C}_{4}$ macrophytes } & \multicolumn{2}{|c|}{ POM } & \multicolumn{2}{|c|}{ Terrestrial plants } \\
\hline & Mean & SD & Mean & $\mathrm{SD}$ & Mean & $\mathrm{SD}$ & Mean & SD \\
\hline \multicolumn{9}{|l|}{ Herbivores } \\
\hline Prochilodus nigricans & 33 & 10 & 7 & 5 & 36 & 10 & 24 & 10 \\
\hline Colossoma macropomum & 28 & 12 & 15 & 9 & 29 & 12 & 28 & 12 \\
\hline Leporinus friderici & 27 & 13 & 7 & 7 & 46 & 14 & 20 & 13 \\
\hline Mylossoma duriventre & 19 & 12 & 28 & 8 & 20 & 11 & 33 & 14 \\
\hline Schizodon fasciatus & 24 & 12 & 28 & 6 & 20 & 10 & 28 & 11 \\
\hline \multicolumn{9}{|l|}{ Detritivores } \\
\hline Potamorhina altamazonica & 32 & 12 & 7 & 6 & 46 & 15 & 15 & 10 \\
\hline Hypoptopoma cf. jobertii & 21 & 14 & 9 & 10 & 50 & 21 & 19 & 13 \\
\hline Psectrogaster rutiloides & 23 & 13 & 16 & 12 & 31 & 15 & 30 & 13 \\
\hline
\end{tabular}

the lowest TP-values, varying between 2.0 (M. duriventre) and 2.9 (L. friderici). Detritivores and invertivores showed intermediate TP-values. Detritivores ranged from 2.3 (P. rutiloides) to 2.8 ( $P$. altamazonica), whereas invertivores varied from 2.7 (Poptella compresa) to 3.0 (M. dichroura). Piscivore fishes showed the highest TP-values, varying between 3.3 (Serrasalmus spilopleura and Serrasalmus rhombeus) and 3.8 (P. fasciatum). Among piscivores, Roeboides affinis, $P$. tigrinum, and $P$. nattereri showed intermediate TP values.

\section{DISCUSSION}

Our data on the basal carbon sources follow the general pattern found in previous studies in neotropical aquatic ecosystems. These studies show that $\delta^{13} \mathrm{C}$ values of $\mathrm{C}_{4}$ aquatic macrophytes are the most enriched carbon source (around -13\%), phytoplankton (mostly measured as POM) is the most depleted carbon source (-33\%o or lower), and terrestrial plant leaves and $\mathrm{C}_{3}$ aquatic macrophytes show intermediate $\delta^{13} \mathrm{C}$ values, varying between -25 $\%$ and $-30 \%$. This pattern was first reported by Araujo-Lima, Forsberg, Victoria, and Martinelli (1986) and has been consistently repeated in subsequent studies (Forsberg et al., 1993; Manetta et al., 2003; Mortillaro et al., 2015). Nevertheless, it is not unusual that the isotopic signal of POM overlaps with that of $\mathrm{C}_{3}$ aquatic macrophytes and terrestrial plants (Wantzen et al., 2002; Pouilly et al., 2013). Variability in $\delta^{15} \mathrm{~N}$ for basal resources in neotropical wetlands is high (Lopes et al., 2009), and no clear pattern for this variability has been found, which enhances the relevance of determining an appropriate baseline for the environment studied, before estimating the trophic positions of the species of the fish assemblage (VanderZanden \& Rasmussen, 1999; Post, 2002).

Among primary consumer fishes, we observed a large contribution of POM-derived carbon to the diet of the herbivores $P$. nigricans and L. friderici. Although P. nigricans feeds on mud and scrapping algae from trunks, items in the stomach content of both species are similar: algae, plant parts, and occasionally arthropods and small fish (Ayala, Zambrana, \& Maldonado, 2000; Pouilly, Yunoki, Rosales, \& Torres, 2004; Sarmiento et al., 2014). POM and $\mathrm{C}_{3}$ macrophytes are the main carbon sources for these species in the floodplain of river Ichilo. Such proportion of carbon derived from POM, resembles the findings of 
Mortillaro et al. (2015) for L. friderici in the Amazon floodplain.

As one could expect for herbivore species feeding mainly on fruits, fresh leaves and seeds of vascular plants (Ayala et al., 2000; De Mérona \& Rankin-de-Mérona, 2004; Pouilly et al., 2004; Sarmiento et al., 2014), C. macropomum, $M$. duriventre and $S$. fasciatus showed lower contributions of POM compared to the herbivores $P$. nigricans and $L$. friderici, and detritivore fishes. C. macropomum obtained similar proportions of carbon from POM, $\mathrm{C}_{3}$ aquatic macrophytes and terrestrial plants, with very low contribution of $\mathrm{C}_{4}$ aquatic macrophytes. In contrast with all other basal $\mathrm{C}$ consumers, $M$. duriventre and $S$. fasciatus did use high proportions of $\mathrm{C}_{4}$ aquatic macrophytes $(28 \%)$. In spite of their high contribution to total primary production (Junk \& Piedade, 1993), it is well known that $\mathrm{C}_{4}$ aquatic macrophytes contribute little carbon to the fish assemblages in tropical floodplains (Hamilton et al., 1992; Forsberg et al., 1993; Manetta et al., 2003; Jackson, Adite, Roach, \& Winemiller, 2013; Mortillaro et al., 2015) probably due to their low digestibility (Mortillaro et al., 2015). Nevertheless, several studies report a few taxa from each fish assemblage using relatively high proportions of $\mathrm{C}$ from $\mathrm{C}_{4}$ - grasses, species from the genera Mylossoma and Schizodon frequently belong to such group (Forsberg et al., 1993; Benedito-Cecilio, Araujo-Lima, Forsberg, Bittencourt, \& Martinelli, 2000; Leite et al., 2002; Manetta et al., 2003; Mortillaro et al., 2015) suggesting that their digestive systems are adapted to assimilate $\mathrm{C}_{4}-\mathrm{C}$. M. duriventre and $S$. fasciatus are not abundant in the floodplain lakes of River Ichilo (less than $2 \%$ of the biomass) (Rejas \& Maldonado, 2000) but they are frequently present all across the Bolivian part of the Amazon basin (Sarmiento et al., 2014).

Detritivore species showed the most ${ }^{13} \mathrm{C}$-depleted signature. Our results showed strong contributions of carbon from POM to the detritivores $P$. altamazonica, $H$. joberti and $P$. rutiloides. These fishes feed on a mixture of mud, decomposing plant materials (detritus) and organic matter deposited from the water column (including algae) (Goulding, Carvalho, \& Ferreira, 1988; Ayala et al., 2000; Pouilly et al., 2004). Sedimented POM is therefore consumed from this mixture. Our data agree with Mortillaro et al. (2015) who found high contributions of POM to the diet of the detritivores Pterygoplichthys multiradiatus (Hancock, 1828) and Semaprochilodus insignis (Jardine, 1841). Based on fatty acids analyses, these authors concluded that microalgae are their main carbon source, selectively assimilated from detritus. The relatively low contribution of terrestrial plants and aquatic macrophytes to these species indicates that leaf litter is poorly assimilated. The high contribution of POM to detritivore fishes is worth being highlighted, since this guild is frequently the most abundant in Amazonian lakes (Siqueira-Souza \& Freitas, 2004; Freitas, Siqueira-Souza, Guimarães, Santos, \& Santos, 2010). Two species of this group ( $P$. altamazonica and $P$. rutiloides) represented nearly $80 \%$ of the biomass of the fish assemblage of one of the lakes studied (Rejas \& Maldonado, 2000).

Some individuals of detritivore fish species had more negative $\delta^{13} \mathrm{C}$ values than POM, the most ${ }^{13} \mathrm{C}$ depleted basal carbon source (Fig. 2). Extremely depleted ${ }^{13} \mathrm{C}$ signal of detritivore fishes seems to occur widely in neotropical floodplains (Wantzen et al., 2002; Pouilly et al., 2013; Mortillaro et al., 2015; AzevedoSilva et al., 2016). In our study, it is possible that the phytoplankton signal is actually more ${ }^{13} \mathrm{C}$ depleted than POM, since POM not only includes phytoplankton, but also material derived from terrestrial vegetation and aquatic macrophytes. The more depleted ${ }^{13} \mathrm{C}$ signal in detritivore fish may be explained by a selective assimilation of phytoplanktonic carbon. An alternative, but non-exclusive explanation is that detritivores derive a portion of its carbon from Methane-oxidizing bacteria (MOB). Methane produced by bacteria in anoxic sediments has very negative $\delta^{13} \mathrm{C}$ values $(-80$ to $-52 \%$ ) (Wantzen et al., 2002; Jones \& Grey, 2004; Deines, Grey, Richnow, \& Eller, 2007). Sanseverino, Bastviken, Sundh, Pickova, and Enrich-Prast (2012) found specific fatty acids 
synthesized by MOB in fish tissues, with organisms containing higher amounts of fatty acids from MOB showing lower $\delta^{13} \mathrm{C}$ values. This demonstrates that biogenic ${ }^{13} \mathrm{C}$-depleted carbon can be transferred in the food web up to fish via MOB.

We did not estimate the contribution of food sources for invertivore and piscivore fish species, since both food classes (invertebrates and fish) are composed of organisms with broad feeding habits, and it is not possible to assign an isotopic signal as a homogeneous unit. Only in the case of the invertivore $M$. dichroura, we can draw some conclusions from our data because it shows a strongly ${ }^{13} \mathrm{C}$ depleted signal. As discussed above, this signal indicates that a large amount of its carbon is derived from phytoplankton and/or MOB. This conclusion is supported by the fact that this species feeds on invertebrates and zooplankton (Pouilly et al., 2004; Rejas, Villarpando, \& Carvajal, 2005) . Zooplankton is known to feed mainly on phytoplankton, which typically has a very negative ${ }^{13} \mathrm{C}$ signal (Araujo-Lima et al., 1986; Forsberg et al., 1993; Manetta et al., 2003). However, methanotrophic bacteria may also contribute a large proportion (up to $45 \%$ ) of the carbon to zooplankton (Sanseverino et al., 2012). Invertebrates, on the other hand, vary widely in their isotopic signal, but it is rather common to find Ephemeroptera, Odonata (Molina et al., 2011) and Diptera (Rejas, 2004; Deines et al., 2007 with ${ }^{13} \mathrm{C}$ signals that are more depleted than the most depleted basal carbon source, probably due to the consumption of MOB.

Trophic position has become a relevant metric to evaluate community structure and dynamics (Post, 2002) and ecosystem degradation (Pauly \& Watson, 2005; Carvalho, Castro, Callisto, Moreira, \& Pompeu, 2015; McCallum et al., 2017). The use of the stable isotope ${ }^{15} \mathrm{~N}$ is considered the most rigorous method of determining trophic position (Carscallen, Vandenberg, Lawson, Martinez, \& Romanuk, 2012), because it offers an especially strong signal for the mean effective trophic level of individuals (Michener \& Kaufman, 2007). However, substantial variations in trophic enrichment factors
(TEFs) among consumers and food sources may occur (McCutchan Jr. et al., 2003). Thus, care must be taken to choose the appropriate TEF. We used a fractionation value of $2.8 \%$, which was obtained independently by Jepsen and Winemiller (2002) as refinement for tropical fishes; and by McCutchan Jr. et al. (2003) for muscle tissue samples without treatment for lipid removal.

In general, we found good concordance between TP and trophic guild assigned based on diet composition from literature. Herbivore and algivore/detritivore species displayed TP values higher than 2.0 that correspond to primary consumers (Vander-Zanden, Cabana, \& Rasmusen, 1997). Herbivores were at the bottom TP, with $M$. duriventre being the baseline organism; therefore being assigned a TP of 2.0. P. nigricans and C. macropomum exhibited TPs near 2.5, the value assigned by Vander-Zanden et al. (1997) to omnivore species. Moreover, $L$. friderici showed a TP of a secondary consumer. Among Algivore/detritivore fishes, P. rutiloides showed the lowest TP value (2.3) compared to $P$. altamazonica (2.8) and H. joberti (2.9). The relatively high TP of most herbivore and algivore/detritivore species is not surprising, since, in spite of being classified as primary consumers, it is well known that these fishes include terrestrial and aquatic arthropods and even occasionally fish in their diet (Pouilly et al., 2004; Sarmiento et al., 2014). Their TP probably varies with food source availability, as these species are opportunistic, being able to adapt their feeding behavior during food shortages by increasing animal food consumption (Mortillaro et al. 2015).

Our results differ from those from Jepsen and Winemiller (2002) who reported extremely low TPs for primary consumers: on average 0.4-0.7 for herbivores and 0.7-1.5 for detritivores. However, this seems to be an artifact of using a baseline with $\delta^{15} \mathrm{~N}$ values higher than those of primary consumers. Nevertheless, our results agree with Jepsen and Winemiller (2002) in the trend of higher TPs for algivore/ detritivore species than for herbivore species. Estimations of the TP of algivore/detritivore 
species in the Iténez (Pouilly et al., 2013) and Purizinha basin (Azevedo-Silva et al., 2016) are also above 2.0, but tend to be lower than our estimations. In the former case, this can be explained because the authors used the detritivore Curimatella cf. alburna (Müller \& Troschel, 1844) as baseline, using an herbivore may have resulted in higher TP values. In the latter case, slightly lower estimations are due to the use of a larger TEF (3.4\%), resulting in lower TP values.

The omnivore/invertivore species studied here, display TPs near the 3.0 value expected for secondary consumers (Vander-Zanden et al., 1997) except for Triportheus angulatus which displays a lower TP (2.5), probably reflecting less frequent use of invertebrates by this species. TPs found for these species fall within the range of variation reported in similar environments (Pouilly et al., 2013; AzevedoSilva et al., 2016).

Several studies on neotropical fish assemblages concluded that food webs are short, with piscivore fishes occupying low trophic positions, at or just above TP 3.0 (Lewis Jr. et al., 2001; Jepsen \& Winemiller, 2002; Layman, Winemiller, Arrington, \& Jepsen, 2005; Pouilly et al., 2013; Azevedo-Silva et al., 2016). According to Lewis Jr. et al. (2001) food webs in these systems are compressed because fish production of the highest trophic level is supported by the lowest trophic level. The wide variations in primary consumer's body size, morphology, habitat affinity, and behavior allow predators to exploit prey at energetically optimal sizes (Layman et al., 2005). However, closer examination of these studies led us to the conclusion that food chain length may have been underestimated. Lewis Jr. et al. (2001) for example, reported more than $40 \%$ of the fish species in the floodplain of the Orinoco River occupying a TP between 3.0 and 3.5, and nearly $5 \%$ of the species occupying a TP between 3.5 and 4.0. Similarly, Layman et al. (2005) found maximum TPs around 3.7 in a tributary of River Orinoco. Jepsen and Winemiller (2002) who studied four rivers with different water types in Venezuela, found a maximum TP of
2.9 (average 2.1), however, they used a rather high $\delta^{15} \mathrm{~N}$ as baseline. If we assign $M$. duriventre the TP of a primary consumer (2.0) and use it as baseline, we get an average TP of 3.8 for the piscivores, with the maximum TP being around 4.6. Pouilly et al. (2013) found maximum TPs between 2.41 and 2.99 for piscivore species in the basin of river Iténez (Bolivia), but they used the detritivore/algivore $C$. $c f$. alburna as baseline. Based on our results, we estimate that using an herbivore as baseline would result in an increase of at least 0.5 in the TPs of piscivore species, which would leave us with a food chain of 2.9-3.5 TPs. AzevedoSilva et al. (2016) estimated TPs of 3.2 for the piscivores Plagioscion sqamosissimus (Heckel, 1840) and Hoplias malabaricus using a TEF of $3.4 \%$. With the corrected TEF used here (2.8 $\%$ ) TP's would increase up to 3.6.

Piscivore fishes were at the top TPs. Two species of piranhas (S. spilopleura and $S$. rhombeus) showed relatively low TP values, similar to those suggested for secondary consumers. Conversely, H. malabaricus (3.7) and $P$. fasciatum (3.8) displayed high TP values, close to 4.0 , the value assigned to tertiary consumers. These data indicate that the fish assemblage from the floodplain of river Ichilo is part of a relatively long food chain. It is possible that the particular characteristics of river-floodplain systems located in the upper-Amazon basin (nutrient-rich white waters, short flood pulse, and long isolation time of the floodplain lakes from the main channel of the river) result in longer food chains. Both, the resource availability and the disturbance hypothesis (Warfe et al., 2013) support this.

Our data suggest that food chains in these particular Amazonian floodplains are longer than previously thought. Because of their high diversity and abundance, detritivore fishes are the most important food source for piscivore fishes. Thus, detritivore fishes play an important role in energy flux and material cycling in these food webs, supporting diversity and biomass of higher trophic levels. The fact that detritivores occupy higher TPs than expected for primary consumers, results in relatively 
long food chains. Determining the relative contribution of the main carbon sources (phytoplankton and/or MOB) and understanding the pathways in which energy flows from these sources towards detritivore fish, is therefore, a major challenge for future studies on food web ecology of tropical river-floodplain systems.

\section{ACKNOWLEDGMENTS}

This research has been funded by of the Flemish Interuniversity Council (VLIR- UOS, Belgium), project ZEIN2010RIP08. Thanks to: Steven Declerck, Paulus Tak, Arne Van den Bogaerde, Carla Fernández, Ruth Diaz, Pascual Montejo and Juan Carlos Rapu for participating on the sampling campaigns; C. Fernández for processing samples; Loreto De Brabandere for stable isotope analysis; Marc Pouilly for helping with statistical analyses; S. Declerck and M. Pouilly for comments on previous versions of the manuscript.

\section{RESUMEN}

Estructura trófica de un ensamblaje de peces en la cuenca alto-Amazónica, Bolivia. Los ensamblajes de peces amazónicos presentan alta diversidad y complejidad trófica. La descripción de su estructura trófica proporciona información útil para su manejo. Con el fin de estimar la contribución de las fuentes básicas de carbono en la dieta de los consumidores primarios, y determinar la posición trófica (PT) de las especies dominantes de peces de cada gremio, analizamos isótopos estables de carbono $\left(\delta^{13} \mathrm{C}\right)$ y nitrógeno $\left(\delta^{15} \mathrm{~N}\right)$ en las fuentes de carbono y en músculo de peces, de la llanura de inundación del río Ichilo. Las plantas terrestres y las macrófitas $\mathrm{C}_{3}$ fueron las mayores fuentes de carbono en la dieta de los peces herbívoros, mientras que la materia orgánica particulada contribuyó más a la dieta de los detritívoros. Las macrófitas $\mathrm{C}_{4}$ contribuyeron poco a la dieta de herbívoros y detritívoros, excepto para Mylossoma duriventre y Schizodon fasciatus, en las que encontramos una contribución relativamente alta (28\%). Encontramos una buena relación entre los valores estimados de PT y el gremio trófico asignado en la literatura. El herbívoro $M$. duriventre estuvo en la base de la red trófica $(\mathrm{PT}=2)$. Los restantes consumidores primarios mostraron valores de PT relativamente altos $(2.3$ - 2.9), probablemente debido a sus hábitos alimenticios oportunistas. Las especies omnívoras/ invertívoras mostraron valores cercanos a 3 . Los peces piscívoros estuvieron en la cima de la red trófica, con PT que variaron entre 3.3 (Serrasalmus spilopleura y Serrasalmus rhombeus) y 3.8 (Pseudoplatystoma fasciatum). Estos datos sugieren que las cadenas tróficas en llanuras de inundación amazónicas, son más largas de lo que se suponía.

Palabras clave: isótopos estables; posición trófica; gremios tróficos; fuentes de carbono; cadena trófica.

\section{REFERENCES}

Abrantes, K. G., Barnett, A., \& Bouillon, S. (2014). Stable isotope-based community metrics as a tool to identify patterns in food web structure in east African estuaries. Functional Ecology, 28, 270-282. doi: $10.1111 / 1365-2435.12155$

Araujo-Lima, C. A. R. M., Forsberg, B. R., Victoria, R. L., \& Martinelli, L. (1986). Energy sources for detritivorous fishes in the Amazon. Science, 234, 1256-1258.

Ayala, G., Zambrana, K., \& Maldonado, M. (2000). Estructura trófica de la ictiocenosis en lagunas de la llanura inundable de los ríos Ichilo y Chapare. Revista Boliviana de Ecología y Conservación Ambiental, 7, 25-35.

Azevedo-Silva, C. E., Almeida, R., Carvalho, D. P., Ometto, J. P. H. B., de Camargo, P. B., Dorneles, P. R., ... Torres, J. P. M. (2016). Mercury biomagnification and the trophic structure of the ichthyofauna from a remote lake in the Brazilian Amazon. Environmental Research, 151, 286-296. doi: 10.1016/j. envres.2016.07.035

Benedito-Cecilio, E., Araujo-Lima, C. A. R. M., Forsberg, B. R., Bittencourt, M. M., \& Martinelli, L. C. (2000). Carbon sources of Amazonian fisheries. Fisheries Management and Ecology, 7, 305-315. doi: 10.1046/j.1365-2400.2000.007004305.x

Busst, G. M. A. \& Britton, J. R. (2017). Comparative trophic impacts of two globally invasive cyprinid fishes reveal species-specific invasion consequences for a threatened native fish. Freshwater Biology, 62, 1587 1595. doi: 10.1111/fwb. 12970

Carscallen, W. M. A., Vandenberg, K., Lawson, J. M., Martinez, N. D., \& Romanuk, T. N. (2012). Estimating trophic position in marine and estuarine food webs. Ecosphere, 3, 1-20. doi: 10.1890/ES11-00224.1

Carvajal, F., \& Maldonado, M. (2005). Influencia de la conexión río-laguna sobre la ictiocenosis lacustre en la várzea del río Ichilo (Cochabamba - Bolivia). Revista Boliviana de Ecología y Conservación Ambiental, 17, 33-48.

Carvalho, D. R., Castro, D., Callisto, M., Moreira, M. Z., \& Pompeu, P. S. (2015), Isotopic variation in five species of stream fishes under the influence of different land uses. Journal of Fish Biology, 87, 559-578. doi:10.1111/jfb.12734 
Coat, S., Monti, D., Bouchon, C., \& Lepoint, G. (2009). Trophic relationships in a tropical stream food web assessed by stable isotope analysis. Freshwater Biology, 54, 1028-1041. doi: 10.1111/j.1365-2427.2008.02149.x

Cucherousset, J., Bouletreau, S., Martino, A., Roussel, J. M., \& Santoul, F. (2012). Using stable isotope analyses to determine the ecological effects of non-native fishes. Fisheries Management and Ecology, 19, 111119. doi:10.1111/j.1365-2400.2011.00824.x

De Carvalho, D. R., de Castro, D. M. P., Callisto, M., Moreira, M. Z., Pompeu, P. S. (2017). The trophic structure of fish communities from streams in the Brazilian Cerrado under different land uses: an approach using stable isotopes. Hydrobiologia, 795, 199-217. doi: 10.1007/s10750-017-3130-6

Deines, P., Grey, J., Richnow, H. H., \& Eller, G. (2007). Linking larval chironomids to methane: Seasonal variation of the microbial methane cycle and chironomid $\delta^{13}$ C. Aquatic Microbial Ecology, 46, 273-282. doi: $10.3354 / \mathrm{ame} 046273$

De Mérona, B., \& Rankin-de-Mérona, J. (2004). Food resource partitioning in a fish community of central Amazon floodplain. Neotropical Ichthyology, 2(2), $75-84$.

Dos Santos, G. M. (1990). Pesca e Ecologia dos peixes de Rondônia. Manaus, AM, Brasil: Fundação Universidade do Amazonas.

Forsberg, B. R., Martinelli, L. A., Victoria, R. L., \& Bonassi, J. A. (1993). Autotrophic carbon sources for fish of the Central Amazon. Ecology, 74(3), 643-652.

Freitas, C. E. C., Siqueira-Souza, F. K., Guimarães, A. R., Santos, F. A., \& Santos, I. L. A. (2010). Interconnectedness during high water maintains similarity in fish assemblages of island floodplain lakes in the Amazonian Basin. Zoologia, 27(6), 931-938. doi: 10.1590/ S1984-46702010000600014

Fry, B. (2006). Stable isotope ecology. New York: Springer.

Goulding, E. G., Carvalho, M., \& Ferreira, L. (1988). Río Negro: Rich life in poor water. The Hague: SPB Academic Publishing.

Gu, B., Schelske, C. L., \& Hoyer, M. V. (1997). Intrapopulation feeding diversity in Blue Tilapia: Evidence from stable-isotope analyses. Ecology, 78(7), 2263-2266

Hamilton, S. K., Lewis Jr., W. M., \& Sippel, S. J. (1992). Energy-sources for aquatic animals in the Orinoco River floodplain: evidence from stable isotopes. Oecologia, 89, 324-330.

Herwig, B. R., Soluk, D. A., Dettmers, J. M., \& Wahl, D. H. (2004). Trophic structure and energy flow in backwater lakes of two large floodplain rivers assessed using stable isotopes. Canadian Journal of Fisheries and Aquatic Sciences, 61(1), 12-22. doi: 10.1139/f03-139

Jackson, A. T., Adite, A., Roach, K. A., \& Winemiller, K. O. (2013). Primary production, food web structure, and fish yields in constructed and natural wetlands in the floodplain of an African river. Canadian Journal of Fisheries and Aquatic Sciences, 70, 543-553. doi: 10.1139/cjfas-2012-0403

Jepsen, D. B., \& Winemiller, K. O. (2002). Structure of tropical river food webs revealed by stable isotope ratios. Oikos, 96(1), 46-55. doi: 10.1034/j.1600-0706.2002.960105.x

Jones, R. I., \& Grey, J. (2004). Stable isotope analysis of chironomid larvae from some Finnish forest lakes indicates dietary contribution from biogenic methane. Boreal Environment Research, 9(1), 17-23.

Junk, W. J., Bayley, P. B., \& Sparks, R. E. (1989). The flood pulse concept in river-floodplain systems. Canadian Special Publication of Fisheries and Aquatic Sciences, 106, 110-127.

Junk, W. J., \& Piedade, M. T. F. (1993). Herbaceous plants of the Amazon floodplain near Manaus: Species diversity and adaptations to the flood pulse. Amazoniana, 12(3/4), 467-484.

Layman, C. A., Winemiller, K. O., Arrington, D. A., \& Jepsen, D. B. (2005). Body size and trophic position in a diverse tropical food web. Ecology, 86(9), 25302535. doi: $10.1890 / 04-1098$

Leite, R. G., Araújo-Lima, C. A. R. M., Victoria, R. L., \& Martinelli, L. A. (2002). Stable isotope analysis of energy sources for larvae of eight fish species from the Amazon floodplain. Ecology of Freshwater Fish, $11,56-63$.

Lewis Jr., W. L., Hamilton, S. K., Rodriguez, M. A., Saunders III, J. F., \& Lasi, M. A. (2001). Foodweb analysis of the Orinoco floodplain based on production estimates and stable isotope data. Journal of the North American Benthological Society, 20, 241-254.

Lopes, C. A., Benedito, E., \& Martinelli, L. A. (2009). Trophic position of bottom-feeding fish in the Upper Paraná River floodplain. Brazilian Journal of Biology, 69(2), 573-581.

Maldonado, M., Goitia, E., \& Rejas, D. (2005). El río Ichilo: un sistema río-llanura de inundación en el alto Amazonas (Bolivia). Revista Boliviana de Ecología y Conservación Ambiental, 17, 69-88.

Manetta, G. I., Benedito-Cecilio, E., \& Martinelli, M. (2003). Carbon sources and trophic position of the main species of fishes of Baía River, Paraná River floodplain, Brazil. Brazilian Journal of Biology, 63(2), 283-290. doi: 10.1590/S1519-69842003000200013 
Marshall, B. G., Forsberg, B. R., \& Peleja, R. (2016) Evidence of mercury biomagnification in the food chain of the cardinal tetra Paracheirodon axelrodi (Osteichthyes : Characidae ) in the Rio Negro, central Amazon, Brazil. Journal of Fish Biology, 89, 220240. doi: $10.1111 / \mathrm{jfb} .12952$

Matsubayashi, J., Morimoto, J. O., Tayasu, I., Mano, T., Nakajima, M., Takahashi, O., Kobayashi, K., \& Nakamura, F. (2015). Major decline in marine and terrestrial animal consumption by brown bears (Ursus arctos). Science Reports, 5, 1-8. doi: 10.1038/ srep09203

McCallum, E. S., Marentette, J. R., Schiller, C., Jindal, S., Empringham, K., Marsh-Rollo, S., ... Balshine, S. (2017). Diet and foraging of Round Goby (Neogobius malastomus) in a contaminated harbor. Aquatic Ecosystem Health \& Management, 20, 252-264. doi: 14634988.2016.1254468

McCutchan Jr, J. H., Lewis Jr, W. M., Kendall, C., \& McGrath, C. C. (2003). Variation in trophic shift for stable isotope ratios of carbon, nitrogen, and sulfur. Oikos, 102, 378-390.

McMeans, B. C., Rooney, N., Arts, M. T., \& Fisk, A. T. (2013). Food web structure of a coastal Arctic marine ecosystem and implications for stability. Marine Ecology Progress Series, 482, 17-28. doi: 10.3354/ meps 10278

Michener, R. H. \& Kaufman, L. (2007). Stable isotope ratios as tracers in marine food webs: An update. In M. Michener, \& K. Lajtha (Eds.), Stable isotopes ecology and environmental science ( $2^{\text {nd }}$ ed., pp. 238282). Oxford: Wiley-Blackwell.

Minagawa, M. \& Wada, E. (1984). Stepwise enrichment of ${ }^{15} \mathrm{~N}$ along food chains: Further evidence and the relation between $\delta^{15} \mathrm{~N}$ and animal age. Geochimica et Cosmochimica Acta, 48(5), 1135-1140. doi: 10.1016/0016-7037(84)90204-7

Molina, C. I., Gibon, F., Oberdorff, T., Dominguez, E., Pinto, J., Marín, R., \& Roulet, M. (2011). Macroinvertebrate food web structure in a floodplain lake of the Bolivian Amazon. Hydrobiologia, 663, 135-153. doi: 10.1007/s10750-010-0565-4

Mortillaro, J. M., Pouilly, M., Wach, M., Freitas, C. E. C., Abril, G., \& Meziane, T. (2015). Trophic opportunism of central Amazon floodplain fish. Freshwater Biology, 60(8), 1659-1670. doi: 10.1111/fwb.12598

Parnell, A. C, Inger, R., Bearhop, S., \& Jackson, A. L. (2010). Source partitioning using stable isotopes: Coping with too much variation. PLoS ONE, 5(3), e9672. doi: 10.1371/journal.pone.000967
Pauly, D., \& Watson, R. (2005). Background and interpretation of the "Marine Trophic Index" as a measure of biodiversity. Philosophical Transactions of the Royal Society: Biological Sciences, 360, 415-423.

Post, D. M. (2002). Using stable isotopes to estimate trophic position: models, methods, and assumptions. Ecology, 83(3), 703-718. doi: 10.2307/3071875

Pouilly, M., Rejas, D., Pérez, T., Duprey, J. L., Molina, C. I., Hubas, C., \& Guimarães, J. R. D. (2013). Trophic Structure and Mercury Biomagnification in Tropical Fish Assemblages, Iténez River, Bolivia. PLoS ONE, 8. doi: 10.1371/journal.pone.0065054

Pouilly, M., Yunoki, T., Rosales, C., \& Torres, L. (2004). Trophic structure of fish assemblages from Mamoré River floodplain lakes (Bolivia). Ecology of Freshwater Fish, 13, 245-257. doi: 10.1111/j.1600-0633.2004.00055.x/full

Rejas, D. (2004). Trophic relations and nutrient recycling in a tropical floodplain lake (Doctoral dissertation). Katholieke Universiteit Leuven, Belgium.

Rejas, D., \& Maldonado, M. (2000). Variaciones espaciotemporales de la composición de la comunidad de peces de una laguna de la várzea del río Ichilo (Cochabamba, Bolivia). Revista Boliviana de Ecología y Conservación, 7, 37-46.

Rejas, D., Muylaert, K., \& De Meester, L. (2005). Nutrient limitation of bacteria and sources of nutrients supporting nutrient-limited bacterial growth in an Amazonian floodplain lake. Aquatic Microbial Ecology, $39,57-67$.

Rejas, D., Villarpando, P., \& Carvajal, F. (2005). Variaciones estacionales en la dieta de Moenkhausia dichroura Kner (Pisces, Characidae) en una laguna de la várzea del río ichilo (Cochabamba - Bolivia). Revista Boliviana de Ecología y Conservación, 17, 49-54.

Rosing, M. N., Ben-David, M., \& Barry, R. P. (1998). Analysis of Stable Isotope Data: A K Nearestneighbors randomization test. Journal of Wildlife Management, 62(1), 380-388.

Sanseverino, A. M., Bastviken, D., Sundh, I., Pickova, J., \& Enrich-Prast, A. (2012). Methane carbon supports aquatic food webs to the fish level. PLoS ONE, 7(8). doi: 10.1371/journal.pone.0042723

Sarmiento, J., Bigorne, R., Carvajal-Vallejos, F. M., Maldonado, M., Leciak, E., \& Oberdorff, T. (2014). Peces de Bolivia/Bolivian fishes. Bolivia: IRD - BioFresh (UE) / Plural Editores. 
Sioli, H. (1984). The Amazon: Limnology and landscape ecology of a mighty tropical river and its basin. Netherlands: Dr. Junk Publishers, Dordrecht.

Siqueira-Souza, F. K., \& Freitas, C. E. C. (2004). Fish diversity of floodplain lakes on the lower stretch of the Solimões river. Brazilian Journal of Biology, 64(3A), 501-510. doi: 10.1590/S1519-69842004000300013

Thébault, E., \& Loreau, M. (2003). Food-web constraints on biodiversity-ecosystem functioning relationships. Proceedings of the National Academy of Sciences of the United States of America, 100(25), 14949-14954.

Vander-Zanden, M. J., Cabana, G., \& Rasmussen, J. B. (1997). Comparing trophic position of freshwater fish calculated using stable nitrogen isotope ratios $\left(\delta^{15} \mathrm{~N}\right)$ and literature dietary data. Canadian Journal of Fisheries and Aquatic Sciences, 1158, 1142-1158. doi: 10.1139/cjfas-54-5-1142

Vander-Zanden, M. J., \& Rasmussen, J. B. (1999). Primary consumer $\delta^{13} \mathrm{C}$ and $\delta{ }^{15} \mathrm{~N}$ and the trophic position of aquatic consumers. Ecology, 80(4), 1395-1404.

Wantzen, K. M., de Arruda-Machado, F., Voss, M., Boriss, H., \& Junk, W. J. (2002). Seasonal isotopic shifts in fish of the Pantanal wetland, Brazil. Aquatic Sciences, 64(3), 239-251. doi: 10.1007/PL00013196

Warfe, D. M., Jardine, T. D., Pettit, N. E., Hamilton, S. K., Pusey, B. J., Bunn, S. E., ... Douglas, M. M. (2013). Productivity, disturbance and ecosystem size have no influence on food chain length in seasonally connected rivers. PLOS ONE, 8(6). doi: 10.1371/journal. pone. 0066240 